\title{
Konseling Analisis Transaksional (AT) Untuk Meningkatkan Perilaku Asertif Warga Binaan Rumah Tahanan Negara Klas 1 Pelabuhan Kota Cirebon
}

\author{
Eha Julaeha $^{1}$, Herny Novianti ${ }^{2}$, Dian Soleh Diana ${ }^{3}$, Nur Fauziyah ${ }^{4}$ \\ IAIN Syekh Nurjati Cirebon, \\ 1 e-mail: eha.iaincirebon@gmail.com \\ 2 e-mail: gusbrava_2111@yahoo.com \\ 3 e-mail: diancever@gmail.com \\ ${ }^{4}$ e-mail: nfauziyah99@gmail.com
}

\begin{abstract}
ABSTRAK
Penelitian ini bertujuan untuk menghasilkan efektifitas Konseling Analisis Transaksional untuk mengembangkan perilaku asertif remaja. Metode penelitian menggunakan pendekatan metode campuran. Sampel dalam penelitian ini adalah remaja RUTAN CLASS I Cirebon, berjumlah 20 remaja. Data dikumpulkan dengan instrumen ketegasan, disusun berdasarkan indikator penerimaan diri, berpikir positif, percaya diri dan memberi serta menerima umpan balik. Hasil penelitian menunjukkan Konseling Analisis Transaksional efektif untuk mengembangkan perilaku asertif remaja. Rekomendasi ditunjukkan untuk program studi bimbingan dan konseling, LAPAS, dan penelitian lebih lanjut.
\end{abstract}

Kata Kunci: Konseling Analisis Transaksional, Perilaku Asertif

\begin{abstract}
This research aimed to produce effectiveness of Transactional Analysis Counseling for increasing adolescence assertive behavior. The method of research used mix method design. The sample in this study were adolescence of RUTAN CLASS I Cirebon, totalling 20 adolescents. Data was collected by assertiveness instrument, arranged on the indicator of self acceptance, positive thingking, self confidence and give and receive feedback. The results showed Transactional Analysis Counseling effective to develop adolescence assertive behavior. Recommendations showed for guidance and counseling study program, LAPAS, and further research.
\end{abstract}

Keywords: Transactional analysis counseling, Assertive behavior 


\section{PENDAHULUAN}

Remaja dalam melangsungkan kehidupannya tidak terlepas dari interaksi teman sebaya yang memiliki karakteristik beragam. Proses interaksi sosial tidak selalu berjalan lancar, remaja sering dihadapkan pada situasi ketidakmampuan menolak ajakan negatif dari teman sebayanya. Pada kenyataannya, tidak semua remaja dapat tinggal bersama keluarganya, terdapat juga remaja yang harus tinggal di Rumah Tahanan (RUTAN). Situasi ketidakmampuan menolak ajakan negatif dari teman sebaya dialami juga oleh warga binaan di RUTAN Klas 1 Pelabuhan Kota Cirebon. Hasil Observasi menunjukkan 63,2\% remaja yang tinggal di RUTAN penghargaan diri yang rendah. Warga binaan mengalami kesulitan dalam mengungkapkan pendapat dan pikirannya, dan sering secara pasif mengikuti apa saja yang menjadi kehendak temannya.

RUTAN Klas 1 Pelabuhan Kota Cirebon merupakan salah satu rumah tahanan negara yang unit pelaksanaan teknis tempat tersangka dan terdakwa ditahan selama proses penyidikan, penuntutan dan pemeriksaan di siding pengadilan. Hal tersebut sesuai dengan Kepmenkeh RI No: M/02/PK04.10 Tahun 1990. Selain merupakan pembinaan terhdap tahanan tapi juga melakukan pembinaan terhadap narapidana. Jumlah warga binaan remaja di Rutan Klas I Pelabuhan Kota Cirebon sebanyak 43 orang. Adapun kasus yang terjadi yaitu pencurian, pelecehan seksual, pembunuhan.

Perilaku yang ditunjukkan oleh warga binaan dapat dipahami mengingat aspek kepribadian remaja yang menonjol dalam berinteraksi sosial adalah social cognition dan konformitas. Dalam (Yusuf \& Nurihsan, 2011) menyatakan social cognition merupakan kemampuan memahami orang lain. Kemampun ini mendorong remaja untuk menjalin hubungan sosial dengan teman sebaya, sedangkan konformitas adalah kecenderungan untuk meniru, mengikuti opini, pendapat, nilai, kebiasaan, kegemaran atau keinginan orang lain. Perkembangan konformitas dapat memberikan dampak positif maupun negatif, tergantung kepada siapa atau kelompok mana remaja melakukan konformitasnya. Sementara itu, Sherif (Effendi, 2013) menyatakan remaja yang memiliki konformitas tingi cenderung mengikuti apa saja yang dikehendaki oleh kelompok teman sebayanya. Ketika dihadapkan pada stimulus yang ambigius dan tidak berstruktur, remaja jarang membangun sudut pandang sendiri yang stabil, dan pandangannya sering berubah ketika dihadapkan pada pandangan orang lain. Semakin rendah kepercayaan diri remaja terhadap penilaiannya sendiri, maka semakin tinggi konformitasnya. Terkait dengan hal itu, remaja perlu memiliki perilaku asertif.

Butler (Harris, 2003) menyatakan perilaku asertif sebagai life postion yang sehat (I'm Ok You're Ok), yang meliputi aspek pikiran, perasaan, dan tindakan. Aspek pikiran ditunjukkan dengan indikator hormat terhadap diri dan orang lain, berpikir positif, bertanggung jawab terhadap 
pendapat yang dituangkan, terbuka terhadap perubahan. Aspek perasaan ditunjukkan dengan indikator percaya diri, dan penghargaan diri. Aspek tindakan ditunjukkan dengan indikator mendengarkan orang lain, melakukan kontak mata langsung, postur tubuh yang terbuka, menerima dan memberi umpan balik.

Pernyataan Butler menjelaskan remaja yang berperilaku asertif adalah remaja yang mampu mengungkapkan pikiran, perasaan, dan tindakan dengan terbuka. Dalam hal ini, individu tersebut dapat membangun interaksi sosial yang menguntungkan dua pihak baik bagi dirinya maupun orang lain. Individu yang berperilaku asertif tidak dilatarbelakangi oleh maksud-maksud tertentu, seperti untuk memanipulasi, memanfaatkan, memperdaya ataupun mencari keuntungan dari orang itu. Sementara itu, Rathus dan Nevid (Weldy, 2009) menyatakan perilaku asertif adalah kemampuan individu yang menunjukkan adanya keberanian untuk secara tegas dan terbuka mengekspresikan kebutuhan, perasaan, dan pikiran apa adanya tanpa menyakiti hati orang lain. Aspek perilaku asertif menurut Rathus dan Nevid adalah pikiran, perasaan, dan kebutuhan.

Program Bantuan Hukum dan Penyuluhan Tahanan (BHPT) yang terdapat di Rutan Klas I Pelabuhan Cirebon memiliki program pembinaan kepribadian, dan kerohanian; konsultasi permasalahan intrapersonal dan interpersonal; membantu segala proses persidangan; bantuan konsultasi hukum dan Bimbingan Mental. Namun dalm pelaksanaannya, Warga binaan Rutan Klas I Pelabuhan Cirebon diberikan pembinaan kepribadian dan kerohanian serta bimbingan mental hanya oleh satu petugas psikolog. Hal tersebut jelas masih terdapat ketidakseimbangan antara jumlah warga binaan Tahun 2018 yang berjumlah 540 orang dengan psikolog yang berjumlah 1 orang. Bukan hanya itu, jumlah warga binaan yang ditampung juga terus mengalami peningkatan setiap tahunnya, sementara daya tampung sangat terbatas. Hal ini jelas mengakibatkan over crowded, diperlukan tambahan fasilitas termasuk petugas psikolog ataupun konselor, agar semua warga binaan dapat mencapai aktualisasi diri.

Berdasarkan penjabaran di atas diperlukan adanya konseling untuk warga binaan sehingga mereka dapat perilaku asertif dengan melibatkan penghormatan diri dan orang lain. Adapun pendekatan konseling yang digunakan yaitu Analisis Transaksional (AT), yang berasumsi bahwa manusia mampu memahami keputusan-keputusan pada masa lalu dan kemudian dapat memilih untuk memutuskan kembali atau menyesuaikan kembali keputusan yang telah pernah diambil. Berne dalam pandangannya meyakini bahwa manusia mempunyai kapasitas untuk memilih dan, dalam menghadapi persoalan-persoalan hidupnya. Analisis Transaksional (AT) lebih menekankan pada aspek kognitif, rasional dan behavioral tentang kepribadian serta berorientasi pada peningkatan kesadaran sehingga konseli mampu membuat keputusan-keputusan dan rencana baru bagi kehidupannya. Dengan demikian, penelitian ini difokuskan kepada Konseling Analisis 
Transaksional Untuk Meningkatkan Perilaku Asertif Warga Binaan Rutan Klas I Pelabuhan Cirebon.

\section{BAHAN DAN METODE}

Konselor dalam Analisis Transaksional berperan sebagai fasilitator yang bersikap terbuka, tanggung jawab, hangat, perhatian, dan tulus. Dalam hal ini, konselor menerangkan konsep analisis transaksional, mendorong, dan membimbing konseli untuk mempercayai ego dewasanya sendiri, sehingga memiliki keterampilan intrapersonal dengan menggunakan status ego yang tepat.

Konseli memiliki berbagai kondisi bentuk ego, yang disebut dengan ego satets yaitu unsurunsur kepribadian yang terskruktur. Adapun ego states tersebut terdiri dari unsur-unsur sebagai berikut:

a. Status Ego Orang Tua, yaitu bagian dari kepribadian yang menunjukkan sifat sifat orang tua, yang berisi perintah. Jika konseli merasa dan bertingkah laku seperti orang tuanya dahulu, maka dapat dikatakan bahwa individu tersebut dalam status ego orang tua. Status ego orang tua merupakan integrasi persaan, sikap, pola pla tingkah laku yang mirip dengan bagaimana orang tua konseli merasa dan bertingkah laku terhadap dirinya.

b. Status Ego Dewasa, yaitu bagian dari kepribadian yang objektif, stabil, tidak emosional, rasional, logis, bekerja dengan fakta dan kenyataan kenyatan, selalu berusaha untuk menggunakan informasi yang tersedia untuk menghasilkan pemecahan yang terbaik dalam pemecahan berbagai masalah.

c. Status Ego Anak, yaitu bagian dari kepribadian yang menunjukkan ketidakstabilan, kreatif, humor, serta inisiatif, masih dalam perkembangan, berubah rubah, ingin tahu dan sebagainya.

Adapun deskripsi pendampingannya sebagai berikut:

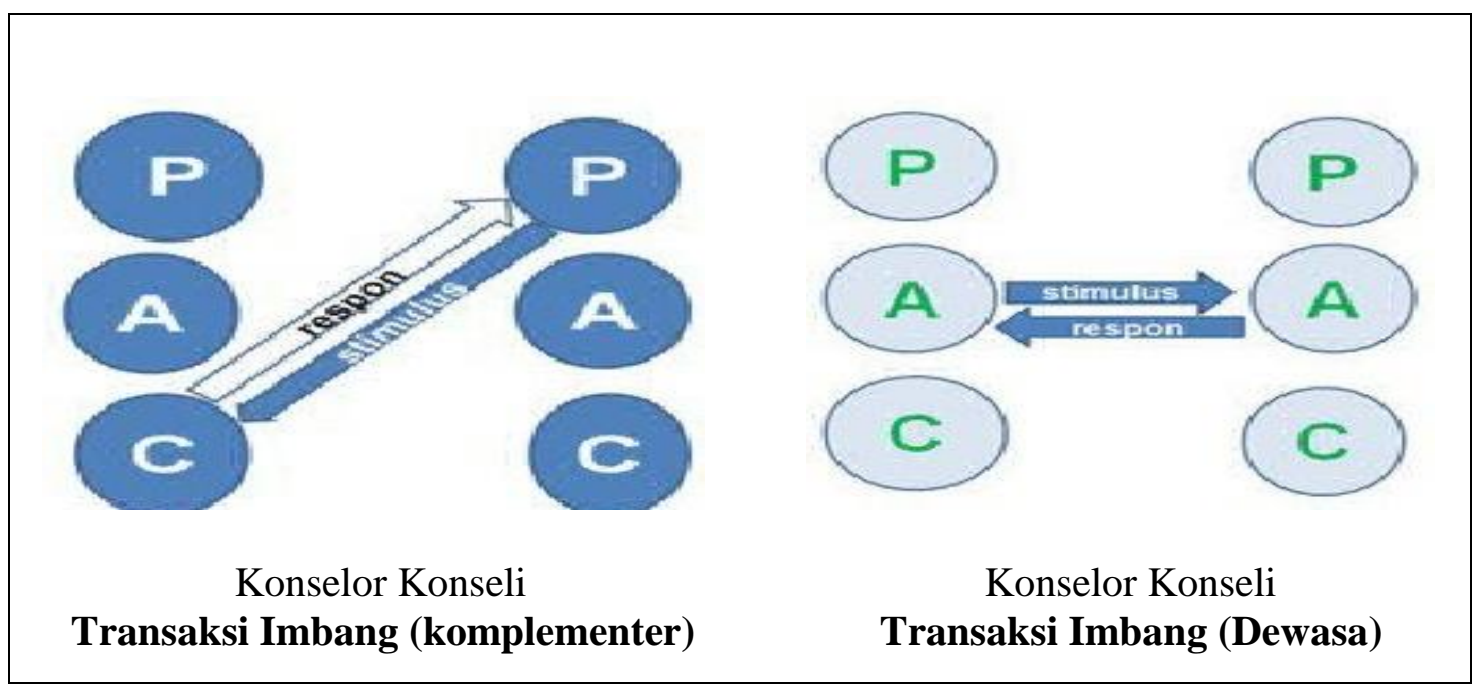

Gambar 1. Deskripsi Pendampingan 
Teknik - teknik konseling analisis transaksional banyak menggunakan teknik - teknik pendekatan Gestalt, yaitu:

1. Metode Didaktik (Didactic Methods)

Karena analisis transaksional menekankan pada domain kognitif, prosedur mengajar dan belajar merupakan dasar dari teori ini.

2. Kursi Kosong (Empty Chair)

Teknik ini merupakan adopsi dari teori Gestalt. Teknik ini biasanya digunakan untuk structural analysis. Teknik yang menggunakan dua kursi ini merupakan cara yang efektif untuk membantu konseli mengatasi konflik masa lalu dengan orang tua atau orang lain pada masa kecil. Tujuan teknik ini adalah untuk menyelesaikan unfinished business masa lalu (Corey, 2010).

3. Bermain peran (Role Playing)

Bermain peran (Role play) biasanya digunakan dalam konseling kelompok dimana melibatkan orang lain. Anggota kelompok lain dapat berperan sebagai ego state yang bermasalah dengan konseli. Dalam kegiatan ini konseli berlatih dengan anggota kelompok untuk beringkah laku sesuai dengan apa yang akan di uji coba di dunia nyata.

4. Penokohan Keluarga (Family Modeling)

Family modeling adalah teori untuk melakukan structural analysis, yang pada umumnya berguna untuk menghadapi constant parent, constant adult atau constant child.

5. Analisis Ritual dan Waktu Luang (Analysis of Rituals and Pastime)

Analisis transaksi termasuk di dalamnya adalah identifikasi ritual dan mengisi wakyu luang (pastime) yang digunakan dalam structuring of time.

Adapun pendekatan penelitian yang digunakan adalah melalui pendekatan mixed method design, seperti yang dinyatakan (Sugiyono, 2013) bahwa didalam mixed method terdapat perpaduan pendekatan kuantitatif dan kualitatif, dimana pendekatan kuantitatif untuk mengkaji tingkat perilaku asertif warga binaan dan menguji keefektifan konseling Analisis Transaksional. Sementara itu, pendekatan kualitatif untuk mengetahui validitas model alternatif konseling Analisis Transaksional dalam meningkatkan perilaku asertif warga binaan.

Model Konseling Analisis Transaksional yang diharapkan adalah model yang dapat memetakan perilaku “I'm OK, You're OK” warga binaan Rutan Klas I Cirebon. Model tersebut disusun berdasarkan need assessment dan hasil analisis di lapangan. Penelitian yang dilakukan menggunakan pendekatan studi eksplorasi dan pengembangan model. Hal tersebut dimaksudkkan agar menghasilkan suatu model alternatif untuk mencapai kondisi yang diinginkan. Sehingga, penelitian dilakukan dengan mendeskripsikan data, fakta, kecenderungan, analisis, dan prediksi. 
Berdasarkan pengkategorian, penelitian ini adalah penelitian kualitatif yang didasari oleh hasil data kuantitaif mengenai perilaku asertif Warga Binaan Rutan sebagai data awal serta datadata kualitatif hasil studi pendahuluan lainnya kemudian mengkaji mengenai kerangka konsep teoriti ideal dari Konseling Analisis Transaksional melalui studi eksplorasi, kemudian mengungkap kondisi di lapangan melalui studi kasus kualitatif, kemudian diarahkan kepada pengembangan model Konseling Analisis Transaksional. Selanjutnya, disampaikan dengan teknik penyajian deskriptif analitik. Studi deskriptif analitik dipergunakan dalam penelitian ini memaparkan data atau karakteristik populasi tertentu secara faktual dan cermat serta menganalisis dan menginterpretasikan data yang ada. Sehubungan karakteristik penelitian deskriptif di atas dalam penelitian ini mengarah kepada studi kasus Konseling Analisis Transaksional pada Warga Binaan Rutan Klas I Pelabuhan Cirebon

\section{HASIL DAN PEMBAHASAN}

Tahapan Konseling Analisis Transaksional untuk mengembangkan perilaku asertif remaja warga binaan RUTAN Klas I Pelabuhan Cirebon dilaksanakan berdasarkan kesepakatan antara peneliti, pihak RUTAN Klas I Pelabuhan Cirebon, dan peserta, baik mengenai waktu ataupun tempat. Kegiatan dilaksanakan dalam 8 kali pertemuan, dalam kurun waktu hampir 2 bulan dan diadakan satu kali dalam seminggu. Untuk pelaksanaan pre-test maupun post-test perilaku asertif diberikan waktu 60 menit, serta untuk kegiatan Konseling Analisis Transaksional diberikan waktu selama 60 menit yang dibagi dalam beberapa sesi (pembagian waktu tiap sesi pertemuan yakni: 5 menit untuk langkah awal, 45 menit untuk kegiatan inti dan 10 menit untuk penutup). Pelaksanaan Konseling Analisis Transaksional ini terbagi menjadi tiga tahapan yaitu:

\section{Tahap Awal (Orientasi)}

Pada tahap ini, peneliti membuka pertemuan, kemudian menjelaskan tentang tujuan kegiatan, peranan peneliti dan peserta dalam kegiatan Konseling Analisis Transaksional. Tahap ini terdiri dari dua sesi pertemuan, yaitu;

a. Pengungkapan kondisi awal, bertujuan agar peserta dapat memahami tujuan umum dan garis besar layanan, juga memahami tujuan pengungkapan perilaku asertif.dan pemahaman umum.

Pada sesi ini, Peneliti membagikan angket perilaku asertif beserta lembar jawabannya. Selanjutnya, menjelaskan cara pengisian angket dan menugaskan peserta untuk mengisi lembar jawaban. Dalam hal ini, peneliti menegaskan pada peserta untuk memilih jawaban yang menggambarkan kondisi peserta. Berikutnya, peserta mengisi lembar jawaban dengan memilih salah satu jawaban yang tersedia, kemudian 
mengumpulkannya setelah selesai mengerjakannya. Sebelum kegiatan berakhir, peneliti menyampaikan bahwa hasil pengungkapan kondisi awal profil perilaku asertif akan diberikan pada pertemuan berikutnya.

b. Pemahaman secara umum mengenai perilaku asertif berdasarkan hasil Pre-test, bertujuan agar peserta memahami kondisi awal perilaku asertif dirinya.

Pada sesi ini, peneliti membagikan lembaran hasil pengungkapan kondisi awal perilaku asertif pada masing-masing peserta, kemudian menjelaskannya. Berikutnya, peserta menyimak penjelasan tersebut dengan melihat lembaran hasil pengungkapan kondisi awal yang telah dibagikan serta diarahkan untuk berperan aktif dalam diskusi. Selanjutnya, peneliti menjelaskan pentingnya layanan Konseling Analisis Transaksional untuk mengembangkan perilaku asertif remaja. Setelah itu, peneliti mempersilahkan peserta untuk bertanya mengenai perilaku asertif. Sebelum kegiatan berakhir, peneliti menyampaikan rangkaian kegiatan selanjutnya dalam rangka mengembangkan perilaku asertif.

2. Tahap Inti

Tahap ini merupakan intervensi yang terdiri dari 7 sub tahap yang mengacu pada model bermain peran yaitu: (a) pemanasan; (b) pemilihan peran; (c) pengaturan adegan; (d) penugasan; (e) pemeranan; (f) pemeranan ulang; (g) berbagi pengalaman dan pengambilan keputusan. Kesembilan sub tahap tersebut dikelompokkan kedalam 5 sesi, diantaranya;

a. Pemanasan dan pemilihan peran, Peserta dapat mengembangkan perilaku asertif yang meliputi indikator penghormatan terhadap diri dan orang lain, berpikir positif, tanggung jawab terhadap pemikirannya dan terbuka terhadap perubahan.

Dalam sesi ini, peneliti mengemukakan tema masalah yang diangkat dari kehidupan sehari-hari peserta, yaitu yang berkaitan dengan interaksi sosial mereka terhadap teman sebayanya, sehingga peserta mengangap bahwa permasalahan tersebut merupakan sebuah wadah yang mewajibkan mereka untuk belajar menghadapi sebuah masalah. Selanjutnya, peneliti menggambarkan permasalahan dengan jelas disertai dengan contoh, yaitu melalui cerita. Permasalahan tersebut muncul dari gambaran yang diberikan oleh peserta. Berikutnya, peserta menyimak cerita yang dibacakan oleh peneliti. Dalam hal ini, cerita dihentikan saat sebuah dilema muncul. Selanjutnya, peneliti mengajukan pernyataan yang membuat peserta berpikir dan memperkirakan akhir cerita. Setelah itu, peneliti dan peserta berdiskusi untuk menggambarkan berbagai karakter yang akan diperankan. Penggambaran karakter terbut diadasarkan atas tuntunan cerita menurut persepsi peneliti dan peserta. Berikutnya, peneliti memberikan kesempatan kepada peserta 
untuk mengemukakan karakter yang dikehendaki, sesuai dengan yang dirasakan peserta. Selanjutnya, peneliti mengajukan tawaran, siapa yang akan menjadi pemeran.

b. Pengaturan adegan dan penugasan, Peserta dapat mengembangkan perilaku asertif yang meliputi indikator Penerimaan diri dan berpartisipasi dalam pergaulan.

Pada sesi ini, peserta yang berperan menjadi pemeran menyusun garis besar adegan yang dimainkan. Dalam hal ini, peneliti menegaskan pada peserta bahwa mereka tidak perlu mempersiapkan dialog khusus. Peserta diminta hanya membuat sketsa adegan dan perkiraan-perkiraan tindakan seorang pemain. Selanjutnya, peneliti berdiskusi dengan peserta mengenai kebutuhan yang diperlukan saat adegan. Berikutnya, peneliti menugaskan pada peserta yang berperan menjadi pengamat untuk menilai: (1) peran yang dimainkan oleh pemain apakah sudah sesuai dengan keadaan yang sebenarnya; (2) bagaimana keefektifan pelaku yang ditunjukkan pemeran; (3) apakah pemeran dapat menghayati peran yang dimainkan. Setelah itu, peneliti memberikan kesempatan pada peserta untuk bertanya perihal pengaturan adegan dan penugasan.

c. Pemeranan, Peserta dapat mengembangkan perilaku asertif yang meliputi indikator percaya diri, penghargaan diri, empati, kontak mata langsung, dan postur tubuh terbuka.

Peserta yang berperan menjadi pemeran menyusun garis besar adegan yang dimainkan. Dalam hal ini, peneliti menegaskan pada peserta bahwa mereka tidak perlu mempersiapkan dialog khusus. Peserta diminta hanya membuat sketsa adegan dan perkiraan-perkiraan tindakan seorang pemain. Selanjutnya, peneliti berdiskusi dengan peserta mengenai kebutuhan yang diperlukan saat adegan. Berikutnya, peneliti menugaskan pada peserta yang berperan menjadi pengamat untuk menilai: (1) peran yang dimainkan oleh pemain apakah sudah sesuai dengan keadaan yang sebenarnya; (2) bagaimana keefektifan pelaku yang ditunjukkan pemeran; (3) apakah pemeran dapat menghayati peran yang dimainkan. Setelah itu, peneliti memberikan kesempatan pada peserta untuk bertanya perihal pengaturan adegan dan penugasan.

Pemain memainkan peran dan menghidupkan situasi secara spontan, dan saling merespon secara realistis. Dalam hal ini, pemeranan cukup dilakukan secara singkat, sesuai dengan tingkat kesulitan dan kompleksitas masalah serta jumlah pemeran yang dilibatkan. Selanjutnya peneliti dan peserta melakukan diskusi dan evaluasi mengenai penafsiran terhadap pemeranan. Berikutnya, peneliti memberikan kesempatan kepada peserta untuk bertanya mengenai pemeranan.

d. Pemeranan ulang, Peserta dapat mengembangkan perilaku asertif yang meliputi indikator menerima dan memberi umpan balik. 
Pemeranan ulang dilaukan jika diskusi pada sesi pemeranan tidak menghasilkan pemahaman utuh kepada peserta mengenai kejadian atau peran tertentu, peneliti meminta reka ulang adegan.

Peneliti memulai kegiatan dengan mengajak peserta berdiskusi mengenai penafsiran baru tentang peran dan memutuskan siapa yang akan kembali memainkan peran. Dalam hal ini, pemeranan ulang dilakukan berdasarkan diskusi dan evaluasi alternatif pemeranan, mungkin ada perubahan watak yang dituntut. Selanjutnya, peneliti menugaskan kepada peserta yang yang berperan menjadi pemain untuk melakukan pemeranan ulang. Setelah itu peneliti memberikan kesempatan kepada peserta untuk bertanya perihal pemeranan yang telah dilakukan.

e. Berbagi Pengalaman dan Pengambilan Kesimpulan, Peserta dapat mengembangkan perilaku asertif yang meliputi indikator mendengarkan orang lain.

Peneliti mengajak peserta untuk berdiskusi mengenai berbagai pengalaman tentang permainan peran yang dilakukan. Hal tersebut dilakukan agar peserta dapat bercermin pada orang lain untuk lebih memahami dirinya. Selanjutnya peneliti memberikan kesempatan pada peserta untuk bertanya. Berikutnya peneliti bersama peserta mengambil kesimpulan dari kegiatan bermain peran.

3. Tahap Akhir (Refleksi)

Tahap ini merupakan refleksi, kegiatan dimulai dengan memberikan angket perilaku asertif. Hal tersebut dimaksudkan untuk mengetahui kondisi akhir perilaku asertif remaja warga binaan Rutan Klas I Pelabuhan Kota Cirebon setelah diberikan perlakuan. Dalam tahapan ini, peneliti membagikan angket perilaku asertif beserta lembar jawabannya. Selanjutnya, menjelaskan cara pengisian angket dan menugaskan peserta untuk mengisi lembar jawaban. Dalam hal ini, peneliti menegaskan pada peserta untuk memilih jawaban yang menggambarkan kondisi peserta. Berikutnya, peserta mengisi lembar jawaban dengan memilih salah satu jawaban yang tersedia, kemudian mengumpulkannya setelah selesai mengerjakannya. 
Adapun berdasarkan hasil kegiatan pendampingan tersebut, didapatkan temuan analisis sebagai berikut;

\section{Profil Perilaku Asertif Remaja}

Tabel 1. Profil Perilaku Asertif Remaja

\begin{tabular}{cccccc}
\hline No & Indikator & Kategori & $\begin{array}{c}\text { Rentang } \\
\text { Skor }\end{array}$ & Frekuensi & Presentase \\
\hline \multirow{2}{*}{1} & Penerimaan & Asertif & $\mathrm{X} \geq 7$ & 13 & $65 \%$ \\
& Diri & Tidak Asertif & $\mathrm{X}<7$ & 7 & $35 \%$ \\
2 & Berpikir & Asertif & $\mathrm{X} \geq 8$ & 12 & $60 \%$ \\
& Positif & Tidak Asertif & $\mathrm{X}<8$ & 8 & $40 \%$ \\
3 & Percaya Diri & Asertif & $\mathrm{X} \geq 6$ & 14 & $70 \%$ \\
& Menerima dan & Asertif & $\mathrm{X} \geq 15$ & 11 & $30 \%$ \\
4 & Memberi & Tidak Asertif & $\mathrm{X}<15$ & 9 & $45 \%$ \\
& Umpan Balik & & & \\
\hline
\end{tabular}

Sumber: Data Primer, 2019

Hasil penelitian menunjukkan profil perilaku asertif warga binaan Rutan Klas I Pelabuhan Kota Cirebon secara umum yakni $45 \%$ berada pada kategori asertif dan 55\% berada pada kategori tidak asertif. Hal tersebut dapat dipahami mengingat aspek kepribadian remaja yang menonjol dalam berinteraksi sosial adalah social cognition dan konformitas.

Perilaku yang ditunjukkan oleh warga binaan dapat dipahami mengingat aspek kepribadian remaja yang menonjol dalam berinteraksi sosial adalah social cognition dan konformitas. (Yusuf \& Nurihsan, 2011) menyatakan social cognition merupakan kemampuan memahami orang lain. Kemampun ini mendorong remaja untuk menjalin hubungan sosial dengan teman sebaya, sedangkan konformitas adalah kecenderungan untuk meniru, mengikuti opini, pendapat, nilai, kebiasaan, kegemaran atau keinginan orang lain. Perkembangan konformitas dapat memberikan dampak positif maupun negatif, tergantung kepada siapa atau kelompok mana remaja melakukan konformitasnya. Sementara itu, Sherif (Effendi, 2013) menyatakan remaja yang memiliki konformitas tingi cenderung mengikuti apa saja yang dikehendaki oleh kelompok teman sebayanya. Ketika dihadapkan pada stimulus yang ambigius dan tidak berstruktur, remaja jarang membangun sudut pandang sendiri yang stabil, dan pandangannya sering berubah ketika dihadapkan pada pandangan orang lain. Semakin rendah kepercayaan diri remaja terhadap penilaiannya sendiri, maka semakin tinggi konformitasnya.

(Anindyajati \& Karima, 2004) menyatakan remaja yang berperilaku asertif memiliki keyakinan serta keberanian untuk bertindak maupun berpendapat, walaupun tindakan dan pemikirannya berbeda dengan lingkungannya. Beberapa ahli (Rees \& Graham, 2006) dan (Bishop, 
2006) menyatakan kebebasan mengungkapkan pikiran dan pendapat merupakan bagian dari perilaku asertif, dimana individu mampu mengungkapkan pikiran dan pendapatnya dengan jelas, langsung dan tepat dengan tetap menghormati dirinya sendiri dan orang lain. Perilaku asertif tidak dilatar belakangi oleh maksud-maksud tertentu, seperti untuk memanipulasi, memanfaatkan, memperdaya ataupun mencari keuntungan dari pihak lain, seperti yang dinyatakan oleh Butler (Harris, 2003) perilaku asertif merupakan life postion yang sehat (I'm Ok You're Ok).

Namun demikian, berdasarkan hasil survei, pada umumnya warga binaan belum sampai pada pencapaian perilaku asertif yang optimal. Berdasarkan persentase tertinggi sampai terendah pada kategori asertif yaitu percaya diri $70 \%$, penerimaan diri $65 \%$, berpikir positif $60 \%$, memberi dan menerima umpan balik $55 \%$.

Pada kenyatannya tidak semua remaja mampu berperilaku asertif bahkan memilih berperilaku tidak asertif, seperti berpura-pura, memendam perasaannya, atau sebaliknya bersikap agresif. Pratanti (Dahlan, 2011) menyatakan bahwa kebanyakan orang enggan bersikap asertif karena dalam dirinya ada rasa takut mengecewakan orang lain, takut jika akhirnya dirinya tidak lagi disukai atau pun tidak diterima. Keinginan untuk mempertahankan kelangsungan hubungan sering dijadikan alasan oleh remaja untuk bersikap tidak asertif. Padahal, dengan membiarkan diri untuk bersikap tidak asertif (memendam perasaan dan perbedaan pendapat), justru akan mengancam hubungan yang ada karena salah satu pihak kemudian akan merasa dimanfaatkan oleh pihak lain.

Terkait dengan perkembangan perilaku asertif, tidak terlepas dari faktor-faktor yang mempengaruhinya, seperti yang dinyatakan oleh (Rathus \& Nevid, 1980): (1) jenis kelamin. Peranan pendidikan laki- laki dan perempuan sejak kecil sudah dibedakan di masyarakat. Lakilaki didik bersikap tegas. Masyarakat mengajarkan bahwa asertif kurang sesuai untuk perempuan, sehingga tampak bahwa perempuan lebih bersikap pasif; (2) kepribadian. Individu yang berperan aktif dalam komunikasi adalah yang memiliki kemampuan untuk mengungkapkan pikirannya secara langsung dan terbuka dengan pendapat orang lain; (3) inteleligensi. Individu yang berperilaku asertif memiliki intelegensi yang baik, sehingga apa yang dipikirkan dan dirasakannya dapat tersampaikan dengan baik kepada individu lain; (4) kebudayaan. Pertama kali individu mengenal kebudayaan dari keluarga. Kebudayaan membentuk kepribadian individu dalam melangsungkan interaksi sosial; (5) usia. Perilaku asertif berkembang sepanjang hidup manusia. Semakin bertambahnya usia maka pengalaman seseorang juga akan terus berkembang, sehingga dengan semakin kompleksnya pengalaman, seseorang akan dapat belajar mengenai hal yang positif bagi dirinya. 


\section{Efektivitas Konseling Analisis Transaksional Untuk Mengembangkan Perilaku Asertif Warga Binaan Rutan Klas I Pelabuhan Kota Cirebon}

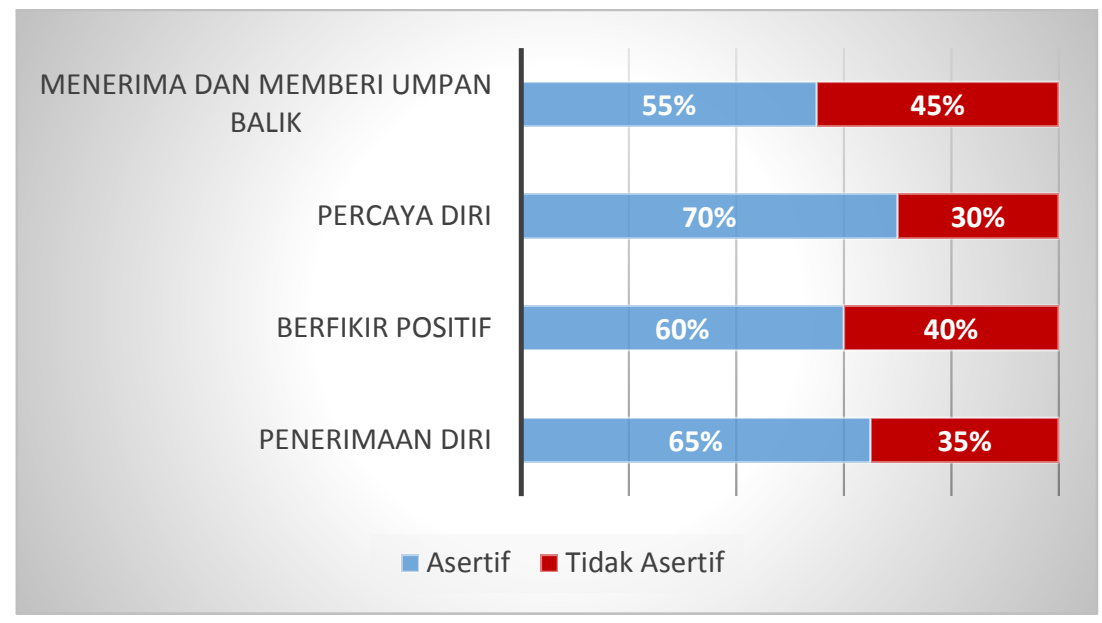

\section{Gambar 2. Gambaran keefektifan Konseling Trasaksional untuk mengembangkan perilaku asertif}

Sumber: Data Primer, 2019

Efektivitas konseling analisis transaksional ditinjau dari segi aspek beserta indikator yang efektif dan tidak efektif serta analisis terhadap faktor yang tidak efektif dalam proses pelaksanaan di lapangan. Keempat indikator yang diberikan kepada remaja pada proses pelaksanaan konseling analisis transaksional yaitu: (1)penerimaan diri;(2) berpikir positif; (3) percaya diri dan member dan menerima umpan balik.

Pengujian efektivitas konseling analisis transaksional dilakukan juga berdasarkan indikator, dan ditemukan dua indikator yang harus ditingkatkan, yaitu berpikir positif, menerima dan member umpan balik. Fakta yang ditemukan selama pelaksanaan konseling analisis transaksional pada indikator memberi dan menerima umpan balik. Hal ini terindikasi dari sebagian warga binaan rutan klas I pelabuhan kota Cirebon yang cenderung tidak memberikan kesempatan kepada temannya saat diskusi berlangsung, bahkan mencemooh temannya dan mengeluarkan pernyataan- pernyataan yang menyinggung perasaan temannya.

Upaya yang dapat dilakukan untuk menumbuhkan memberi dan menerima umpan balik yang baik yaitu menggiringnya menuju kesadaran akan kepedulian terhadap orang lain disekitarnya. Kesadaran akan keberadaan orang lain merupakan faktor penting untuk mengembangkan feed back yang baik. Selain itu juga, faktor kematangan kognitif berpengaruh terhadap kemampuan feed back. Untuk memahami kondisi orang lain diperlukan kematangan kognisi bukan hanya sekedar proses berpikir, sehingga dapat memahami penderitaan orang lain tanpa harus benar-benar mengalaminya. 


\section{KESIMPULAN DAN SARAN}

Kesimpulan hasil studi dan pengembangan Konseling Analisis Transaksional untuk meningkatkan perilaku asertif remaja dipaparkan sebagai berikut.

1. Kesimpulan Umum

Pengabdian berbasis riset ini menghasilkan model Konseling Analisis Transaksional untuk meningkatkan perilaku asertif remaja, yang telah dikembangkan secara teoretik dan empiris. Untuk menghasilkan model konseling tersebut ditempuh prosedur penelitian yang meliputi studi pendahuluan, pengembangan konseling analisis transaksional, uji kelayakan konseling analisis transaksional, dan uji coba konseling analisis transaksional. Hasil studi menunjukkan bahwa konseling analisis tarnsaksional efektif untuk meningkatkan perilaku asertif remaja.

2. Kesimpulan Khusus

a. Profil umum perilaku asertif warga binaan Rutan I Pelabuhan Kota Cirebon menunjukkan kategori asertif rendah pada indikator menerima dan member umpan balik.

b. Konseling analisis transaksional terbukti efektif untuk meningkatkan perilaku asertif warga binaan Rutan Klas I Pelabuhan Kota Cirebon.

Diperlukan strategi yang cerdas sehingga permasalahan keterampilan intrapersonal dan interpersonal warga binaan dapat teratasi, salah satunya yaitu Konseling Sebaya. Pelatihan Konseling teman sebaya merupakan rencana tindak lanjut yang akan diberikan di RUTAN Kelas I Pelabuhan Kota Cirebon. Konseling sebaya memungkinkan individu untuk memiliki keterampilan - keterampilan guna mengimplementasikan pengalaman kemandirian dan kemampuan mengontrol diri yang sangat bermakna bagi remaja. Secara khusus konseling teman sebaya tidak memfokuskan pada evaluasi isi, namun lebih memfokuskan para proses berfikir, proses proses perasaan dan proses pengambilan keputusan. Dengan cara yang demikian, konseling sebaya memberikan kontribusi pada dimilikinya pengalaman yang kuat yang dibutuhkan oleh para remaja yaitu penghormatan terhadap diri dan orang lain.

\section{UCAPAN TERIMA KASIH}

Ucapan terima kasih kami sampaikan kepada LP2M IAIN Syekh Nurjati Cirebon yang telah memonitoring kegiatan, juga kepada Kepala Rutan I Pelabuhan Kota Cirebon beserta para warga binaan yang telah berpartisipasi aktif dalam pelaksanaan Konseling Analisis Transaksional (AT) Untuk Meningkatkan Perilaku Asertif Warga Binaan Rumah Tahanan Negara Klas 1 Pelabuhan Kota Cirebon. 


\section{DAFTAR PUSTAKA}

Anindyajati, M., \& Karima, C. (2004). Peran Harga Diri Terhadap Assertivitas Remaja Penyalahgunaan Narkoba. Jurnal Psikologi, 2(1), 49-73.

Bishop, S. (2006). Develop Your Assertiveness. London: Kogan Page.

Corey, G. (2010). Teori dan Praktek Konseling dan Psikoterapi. Bandung: Refika Aditama.

Dahlan, H. . (2011). Model Konseling Singkat Berfokus Solusi (Solution- Focused Brief Counseling) dalam Setting Kelompok untuk Meningkatkan Daya Psikologis Mahasiswa. Bandung.

Effendi, M. (2013). Hubungan Antara Konsep Diri dan Pola Asuh Orang Tua Dengan Konformitas Santri. Jurnal Penelitian Humaniora, 14(1), 1-8.

Harris, T. A. (2003). I'm OK, You're OK. Washington: Bundle.

Rathus, S. ., \& Nevid, J. . (1980). Behavior Therapy of Solving Problem in Living. New York: The New American Library.

Rees, S., \& Graham, R. (2006). Assertion Training. Taylor: Routledge.

Sugiyono. (2013). Metodologi Penelitian Kuantitatif, Kualitatif, R\&D. Bandung: Alfabeta.

Weldy, T. . (2009). Learning Organiation and Transfer; Strategis for Improving Performance. Journal The Learning Organization, 16(1), 58-68.

Yusuf, S., \& Nurihsan, J. (2011). Landasan Bimbingan Dan Konseling. Bandung: Rosda Karya. 